\title{
ASSOCIATION OF $\beta$-ADRENORECEPTION SYSTEM GENE POLYMORPHISMS AND NON-TOXIC GOITER IN PATIENTS WITH HEART FAILURE*
}

\author{
Pyvovar S.M., Rudyk Yu.S., Lozyk T.V., Galchinska V.Yu., Bondar T.M.
}

Government Institution "L.T.Malaya Therapy National Institute of the National Academy of Medical Sciences of Ukraine", Kharkiv

Прогнозування перебігу серцевої недостатності є актуальним завданням сучасної медичної науки. 3 урахуванням зростання поширеності захворювання з віком пацієнтів, необхідно враховувати наявність коморбідної патології. Метою роботи було вивчення взаємозв'язку між генними поліморфізмами $\beta$-адренорецепторної системи з нетоксичним зобом (НЗ) та перебігом СН. Матеріали і методи. Всього 285 пацієнтів з СН на тлі післяінфарктного кардіосклерозу були включені в дослідження. 3 них у 158 (55,42\%) пацієнтів була коморбідно несприятлива патологія H3. Генотипування 4 поліморфізмів (Gly389Arg гена $\beta 1$-адренорецептора, ген Ser49Gly гена $\beta 1$-адренорецептора

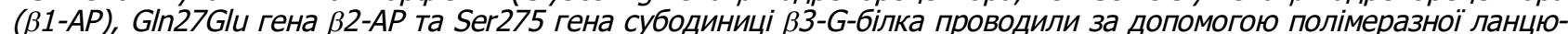
гової реакції (ПЛР). Генетичний та епідеміологічний аналіз проводили за допомогою програмного забезпечення SNPStats. Наявність G-алеля поліморфізму Ser49Gly гена $\beta 1$-AP пов'язано зі збільшенням швидкості розвитку Н3 (модель рецесивної спадковості, $\left.\chi^{2}=3,719, p=0,039\right)$. Ми виявили тенденцію до збільшення швидкості розвитку H3 (на 5,9\%) за наявності поліморфізму алеля C гена Ser275 GN33 (рецесивна модель спадковості, $\chi^{2}=3,452$, $p=0,068) .1-A P$ пов'язано зі збільшенням швидкості розвитку NTG (модель рецесивної спадковості, $\chi^{2} 2=3,719$, $p=0,039)$. Ми виявили тенденцію до збільшення швидкості розвитку НТГ (на 5,9\%) за наявності поліморфізму алеля C гена Ser275 GN $\beta 3$ (рецесивна модель спадковості, $\left.\chi^{2}=3,452, p=0,068\right)$. Ризик розвитку синдрому "низького трийодтироніну" у хворих на ВЧ, що працює на тлі HTГ, збільшується в гомозиготах (G / G) відповідно до поліморфізму Ser49Gly (c, 145A> G) гена $\beta 1$-AP (відношення шансів $(O R)=9,19(3,69-22,90), r=0,044)$. У пацієнтів із CH, що протікає на тлі H3, при наявності поліморфізму алельного G Gln27Glu (c, 79C> G) гена $\beta 2-A P$, ризик досягти комбінованої кінцевої точки протягом двох років $(O R=3,05(1,10-8,43)$ збільшується в гомозиготному стані, a $O R-3,38(1,47-7,82)$ у гетерозигот, при $p=0,008)$, ризик також збільшується у гетерозиготних $(G / C)$ пацієнтів iз Gly389Arg (c, 1165G> C) поліморфізм гена $\beta 1$-AR у присутності H3 $(O R=2,09(1,00-4,37), p=0,046)$. Встановлено, що вроджені генетичні відмінності в шляхах $\beta$-адренорецепції можуть бути пов'язані з розвитком нетоксичного зоба та віддаленим перебігом серцевої недостатності.

Ключові слова: серцева недостатність, нетоксичний зоб, синдром «низького три йодтироніну», прогноз.

Predicting the course of heart failure (HF) is an urgent task of modern medical science. Given the increasing prevalence of the disease with age, it is necessary to take into account the presence of comorbid pathology. The aim of the research was to study the relationship between gene polymorphisms of the $\beta$-adrenoceptor system with non-toxic goiter (NTG) and the HF course. Materials and methods. The total of 285 patients with HF against the background of postinfarction cardiosclerosis were included into the study. Of these, 158 (55.42\%) patients had a comorbidly unfavorable pathology - NTG. Genotyping of 4 polymorphisms (Gly389Arg of the $\beta_{1}$-adrenoreceptor gene, Ser49Gly gene of the $\beta_{1^{-}}$ adrenoceptor $\left(\beta_{1}-A P\right)$ gene, GIn27Glu of the $\beta_{2}-A P$ gene and Ser275 of the $\beta_{3}$ - G-protein subunit gene was performed usingpolymerase chain reaction (PCR). Genetic and epidemiological analysis was performed using the SNPStats software. The obtained results. The presence of the G-allele of the Ser49Gly polymorphism of the $\beta_{1}-A P$ gene is associated with an increase in the rate of NTG development (recessive heredity model, $\chi^{2}=3.719, p=0.039$ ). We found a tendency to the increase of NTG development rate (by 5.9\%) in the presence of the allele C polymorphism of Ser275 gene GN $\beta_{3}$ (recessive model of heredity, $\left.\chi^{2}=3,452, p=0,068\right)$. The risk of "low triiodothyronine" syndrome development in patients with $H F$, running against the background of NTG increases in homozygotes ( $G / G$ ) according to the polymorphism Ser49Gly $(c, 145 A>G)$ of the $\beta 1-A R$ gene (odds ratio $(O R)=9.19(3.69-22.90), g=0.044)$. In patients with HF, which runs against the background of NTG, with the presence of the $G$ allele polymorphism Gln27Glu $(C, 79 C>G)$ of the $\beta 2-A P$ gene, the risk of reaching a combined endpoint within two years (OR $=3.05(1.10-8.43)$ increases in a homozygous state and $O R=3.38(1.47-7.82)$ in heterozygotes, at $p=0.008)$, the risk also increases with heterozygous $(G / C)$ patients with the Gly389Arg ( $c, 1165 G>C)$ polymorphism of the $\beta 1-A R$ gene in the presence of NTG (OR = 2.09 (1.004.37), $p=0.046)$. Conclusion. Congenital genetic differences in $\beta$-adrenoceptor pathways may be associated with the development of non-toxic goiter and the long-term course of heart failure.

Key words: heart failure, non-toxic goiter, low triiodothyronine syndrome, prognosis.

Predicting the heart failure course $(\mathrm{HF})$ is an urgent task of modern medical science. Given the increasing prevalence of the disease with age, it is necessary to consider the presence of co-morbid pathology [1]. In our country, the number of patients with thyroid gland (TG) pathology is growing [1]. Non-toxic goiter (NTG) is the most common TG pathology [2]. One of the factors causing NTG development is genetic polymorphisms, including the $\beta$-adrenoreception system ( $\beta$-ARs) [3].

There is little information in the literature concerning the influence of $\beta$-ARs gene polymorphisms on NTG development, but there are many contradictory data about

\footnotetext{
* To cite this english version Pyvovar S.M., Rudyk Yu.S., Lozyk T.V., Galchinska V.Yu., Bondar T.M. Association of $\beta$-adrenoreception system gene polymorphisms and non-toxic goiter in patients with heart failure. // The Medical and ecological problems. - 2019. - Vol 23, № 5-6. - P. 30-35.
} 
their association with HF. This encourages new research in this field.

The aim of the research was to investigate the interaction of $\beta$-ARs gene polymorphisms with NTG and HF course.

\section{Materials and methods}

The protocol of this prospective cohort study was approved by the local Ethics and Deontology Committee of the Therapy Institute. All study procedures with patients' participation were performed in compliance with the ethical standards of the Helsinki Declaration. Patients were enrolled into the study during their hospitalization at the heart disease department due to HF decompensation.

The study included 285 patients with HF (82 women and 203 men) of the Caucasian race. Criteria for involvement: signed informed consent, history of myocardial infarction (Ml), verified diagnosis of HF-II-IV FC by NYHA. Exclusion criteria: not signing the informed consent, hemodynamically significant valvular cardiac defects, HF of other aetiology than cardiac infarction induced cardiosclerosis, thyroid suppressive treatment, clinical hypothyroidism, thyrotoxicosis, inflammatory diseases, other serious pathologies (tumors, tuberculosis) that could complicate treatment or reduce the life expectancy.

The control group consisted of 55 healthy individuals (without CHD, HF, thyroid pathology), 18 women $(32.7 \%$ ) and 37 men $(67.3 \%)$ among them. The mean age was 57.00 [52.00 - 65.00] years. Statistical analysis revealed no significant difference in the frequency distribution by sex and age between the control group and the HF patients (table 1).

Diagnosis of HF and treatment of patients were performed in compliance with the recommendations of the European Society of Cardiologists [4].

To determine the serum thyroid stimulating hormone (TSH) (normal range - $0.3-4.0 \mathrm{mlU} / \mathrm{L}$ ), free T3 $\left(\mathrm{T}_{\mathrm{f}}\right)$ (normal range - 2.5-5.8 pmol/l) and free T4 $\left(\mathrm{T}_{\mathrm{f}}\right)$ (normal range - 10-25 $\mathrm{pmol} / \mathrm{l}$ ) the reagent kits ("TSH- ELISA", " $\mathrm{T}_{4 \mathrm{f}}$-ELISA" and "T $\mathrm{T}_{3 \mathrm{f}}$ ELLISA" from "Hema", Ukraine) were used. Enzyme-linked immunosorbent assays were performed with an Immunochem-2100 semi-automatic enzyme-linked immunosorbent analyzer (High technology,

USA). 63 patients were diagnosed with "low triiodothyronine syndrome" (LTS) at $\mathrm{T}_{3 \mathrm{f}}$ level $\leq 2.07 \mathrm{pmol} / \mathrm{L}$ at normal $\mathrm{T}_{4 \mathrm{f}}$ and $\mathrm{TSH}$ levels [5].

Patients were monitored for 2 years, taking into account the events of re-hospitalization $(\mathrm{RH})$ for the HF decompensation (or intravenous administration of loop diuretics as prescribed by a cardiologist). Mortality was considered. The combined endpoint (CEP) was defined as a combination of death and hospitalization (or intravenous diuretics administration).

The first group included 127 (44.56\%) patients with HF without NTG. The second group included 158 $(55.42 \%)$ patients with HF in combination with NTG. The diagnosis of NTG was established by the ultrasound study (ultrasonography). During ultrasonography, the size of thyroid gland was assessed, the presence of focal formations - their localization, size, echogenicity (diffuse nodes: normal, hyper- and hypogenic; anechogenic cysts), internal structure (homo- or heterogeneous); borders (clear and smooth or fuzzy, irregular contours), the nature of calcificates (micro- or macro- calcificates), vascularization of the entire pulp, and focal changes (color Doppler studies). Groups of patients did not differ by sex and age.

The total of 4 polymorphisms were selected in 3 genes. Table 1 presents the specific primers for genotyping. The laboratory staff did not know which group the patients belonged to; $10 \%$ of all the DNA samples were genotyped repeatedly for quality control. Blood for molecular genetic studies was collected in VACUTEST vacutainers with K3EDTA. DNA was isolated from the whole blood using the "DNA sorb-B" ("Amplisens", RF) reagents kit. The isolated DNA was stored before amplification at minus $20^{\circ} \mathrm{C}$ for no more than 3 months. Genotyping of polymorphic sites in $\beta_{1}$-adrenoreceptor $\left(\beta_{1}\right.$-AR) genes (rs1801253; c.1165G> C; p.Gly389Arg), $\beta_{2^{-}}$ adrenoreceptors $\quad\left(\beta_{2}-\mathrm{AR}\right) \quad(\mathrm{rs} 1042714 ; \quad$ c.79C> $\quad \mathrm{G}$; p.GIn27Glu) and the G-protein $\beta_{3}$-subunit gene $\left(\mathrm{GN} \beta_{3}\right)$ (rs5443; c.825C> T; p.Ser275 =) was performed by means of the real-time polymerase chain reaction (PCR $\mathrm{RT}$ ) using "Sintola" reagent kits according to the manufacturer's instructions.

Table 1 Characterization of polymorphisms under study

\begin{tabular}{|c|c|c|c|c|}
\hline Gene & Polymorphism & Base substitution & $\begin{array}{l}\text { Amino-acid } \\
\text { substitution }\end{array}$ & $\begin{array}{c}5^{\prime}-3^{\prime}(F)-\text { и 3'-5'(R)-primers for polymerase chain } \\
\text { reaction }\end{array}$ \\
\hline$\beta_{1}-\mathrm{AR}$ & rs1801253 & c. $1165 G>C$ & Gly389Arg & $\begin{array}{l}\text { F: ccccgacttccgcaaggccttccag } \\
\text { R: gactgctctgctgcgcgcgcagggc }\end{array}$ \\
\hline$\beta_{1}-\mathrm{AR}$ & rs1801252 & c. $145 A>G$ & p.Ser49Gly & $\begin{array}{l}\text { F: ctcgttgctgcctcccgccagcgaa } \\
\text { R: gccccgagccgctgtctcagcagtg }\end{array}$ \\
\hline$\beta_{2}-\mathrm{AR}$ & rs1042714 & c. $79 \mathrm{C}>\mathrm{G}$ & p.GIn27Glu & $\begin{array}{l}\text { F: tgcgccggaccacgacgtcacgcag } \\
\text { R:aaagggacgaggtgtgggtggtggg }\end{array}$ \\
\hline $\mathrm{GN} \beta_{3}$ & rs 5443 & c. $825 \mathrm{C}>\mathrm{T}$ & p.Ser275= & $\begin{array}{l}\text { F: agagcatcatctgcggcatcacgtc } \\
\text { R: gtggccttctccctcagtggccgcc }\end{array}$ \\
\hline
\end{tabular}

For genotyping of the Ser49Gly polymorphism of the $\beta_{1}$-AR gene (rs1801252; c.145A> G; p.Ser49Gly), TaqMan SNP Genotyping Assay (Assay ID C_8898508_10) and Universal PCR Master Mix (Ref. 4304437) (Thermo Fisher Scientific, USA) were used in compliance with TaqMan® Universal PCR Master Mix USER GUIDE (Applied Biosystems by Life Technologies). Amplification was performed using CFX96 Touch (BioRad) Real-Time PCR Products Detection System.
CFX Manager Software was used for allelic discrimination. All the polymorphisms under study were in HardyWeinberg equilibrium. This eliminated the probability of a genotyping error.

Statistical processing was performed using IBM ${ }^{\circledR}$ SPSS $®$ Statistics, 20.0 software packages (freedownload full Version). Genetic and epidemiological analysis was carried out using the SNPStats online software program. 


\section{Results and discussion}

The study has demonstrated that the of the Ser49Gly polymorphism G-allele presence in the $\beta_{1}$-AR gene is associated with the increased rate of NTG development (recessive heredity model, $\chi^{2}=3.719, p=0.039$ ). There was also a tendency to increase the rate of NTG devel- opment (by $5.9 \%$ ) in the presence of $\mathrm{C}$ allele of the Ser275 gene polymorphism $\mathrm{GN} \beta_{3}$ (recessive model of heredity, $\chi^{2}=3.452, p=0.068$ ). There were no statistically significant differences found for other polymorphisms under study (table 2).

Interaction between $\beta$-ARs and NTG genes polymorphisms in patients with HF

\begin{tabular}{|c|c|c|c|c|c|c|}
\hline $\begin{array}{c}\text { Model } \\
\text { of heredity }\end{array}$ & Genotype & $\begin{array}{c}\text { Without NTG } \\
(n=127)\end{array}$ & $\begin{array}{l}\text { With NTG } \\
(n=158)\end{array}$ & OR $(95 \% \mathrm{Cl})$ & $\mathrm{p}$ & HWE \\
\hline 1 & 2 & 3 & 4 & 5 & 6 & 7 \\
\hline \multicolumn{7}{|c|}{ Polymorphism of Ser49Gly gene $\beta_{1}$-AP $(n=285)$} \\
\hline \multirow{3}{*}{$\begin{array}{l}\text { Co- } \\
\text { dominant }\end{array}$} & G/G & $92(71.9 \%)$ & $119(75.8 \%)$ & 1.00 & \multirow{3}{*}{0.11} & \multirow{10}{*}{0.44} \\
\hline & $\mathrm{A} / \mathrm{G}$ & $33(25.8 \%)$ & $38(24.2 \%)$ & $0.90(0.52-1.55)$ & & \\
\hline & $\mathrm{A} / \mathrm{A}$ & $3(2.3 \%)$ & $0(0 \%)$ & $0.00(0.00-N A)$ & & \\
\hline \multirow{2}{*}{ Dominant } & $\mathrm{G} / \mathrm{G}$ & $92(71.9 \%)$ & $119(75.8 \%)$ & 1.00 & \multirow{2}{*}{0.5} & \\
\hline & $\mathrm{A} / \mathrm{G}-\mathrm{A} / \mathrm{A}$ & $36(28.1 \%)$ & $38(24.2 \%)$ & $0.83(0.49-1.42)$ & & \\
\hline \multirow[t]{2}{*}{ Recessive } & $\begin{array}{l}\text { G/G } \\
A / G\end{array}$ & $125(97.7 \%)$ & $157(100 \%)$ & 1.00 & \multirow[t]{2}{*}{0.039} & \\
\hline & $\mathrm{A} / \mathrm{A}$ & $3(2.3 \%)$ & $0(0 \%)$ & $0.00(0.00-N A)$ & & \\
\hline \multirow{2}{*}{$\begin{array}{l}\text { Over- } \\
\text { dominant }\end{array}$} & G/G-A/A & $95(74.2 \%)$ & $119(75.8 \%)$ & 1.00 & \multirow{2}{*}{0.78} & \\
\hline & A/G & $38(24.2 \%)$ & $11(17.5 \%)$ & $0.93(0.54-1.60)$ & & \\
\hline $\begin{array}{l}\text { Log- } \\
\text { additive }\end{array}$ & - & - & - & $0.77(0.46-1.27)$ & 0.31 & \\
\hline \multicolumn{7}{|c|}{ Поліморфрізм Ser275 гена GN $\beta_{3}(n=284)$} \\
\hline \multirow{3}{*}{$\begin{array}{l}\text { Co- } \\
\text { dominant }\end{array}$} & $\mathrm{C} / \mathrm{C}$ & $65(51.2 \%)$ & $84(53.5 \%)$ & 1.00 & \multirow{3}{*}{0.19} & \multirow{10}{*}{1} \\
\hline & $\mathrm{C} / \mathrm{T}$ & $48(37.8 \%)$ & $65(41.4 \%)$ & $1.03(0.62-1.69)$ & & \\
\hline & $T / T$ & $14(11 \%)$ & $8(5.1 \%)$ & $0.44(0.17-1.12)$ & & \\
\hline \multirow{2}{*}{ Dominant } & $\mathrm{C} / \mathrm{C}$ & $65(51.2 \%)$ & $84(53.5 \%)$ & 1.00 & \multirow{2}{*}{0.65} & \\
\hline & $\mathrm{C} / \mathrm{T}-\mathrm{T} / \mathrm{T}$ & $62(48.8 \%)$ & $73(46.5 \%)$ & $0.90(0.56-1.44)$ & & \\
\hline \multirow{2}{*}{ Recessive } & $\mathrm{C} / \mathrm{C}-\mathrm{C} / \mathrm{T}$ & $113(89 \%)$ & $149(94.9 \%)$ & 1.00 & \multirow{2}{*}{0.068} & \\
\hline & $\mathrm{T} / \mathrm{T}$ & $14(11 \%)$ & $8(5.1 \%)$ & $0.44(0.18-1.08)$ & & \\
\hline \multirow{2}{*}{$\begin{array}{l}\text { Over- } \\
\text { dominant }\end{array}$} & $\mathrm{C} / \mathrm{C}-\mathrm{T} / \mathrm{T}$ & $79(62.2 \%)$ & $92(58.6 \%)$ & 1.00 & \multirow{2}{*}{0.59} & \\
\hline & $\mathrm{C} / \mathrm{T}$ & $48(37.8 \%)$ & $65(41.4 \%)$ & $1.14(0.70-1.85)$ & & \\
\hline $\begin{array}{l}\text { Log- } \\
\text { additive }\end{array}$ & - & - & - & $0.81(0.56-1.17)$ & 0.26 & \\
\hline
\end{tabular}

Notes: AIC- Akaike Information Criterion; HWE - Hardy-Weinberg equilibrium.

In our previous works, it has been demonstrated that in NTG patients with HF the incidence of LTS is high [6], which is likely to be attributed to a high risk of rehospitalization within 2 years due to HF decompensation [6]. The analysis of $\beta$-ARs gene polymorphisms association with the frequency of LTS development in patients with HF course against the background of NTG was performed. It is established that the risk of LTS development in patients with HF, against the background of NTG, increases in homozygotes ( $G / G)$ according to the Ser49Gly polymorphism (c, $145 \mathrm{~A}>\mathrm{G}$ ) of the $\beta 1$-AR gene $(\mathrm{OR}=9.19(3.69-22.90), \mathrm{p}=0.044)($ table 3$)$.

Table 3

Associations of LTS frequency with polymorphisms of $\beta$-ARs genes in NTG in patients with HF

\begin{tabular}{|c|c|c|c|c|c|c|}
\hline \multicolumn{7}{|c|}{ Ser49Gly polymorphism $(\underline{c}, 145 A>G)$ of $\beta_{1}$-AP gene $(n=281)$} \\
\hline \multirow{2}{*}{$\begin{array}{c}\text { Poly- } \\
\text { morphism }\end{array}$} & \multicolumn{3}{|c|}{ Without NTG $(n=124)$} & \multicolumn{3}{|c|}{ With NTG $(n=153)$} \\
\hline & $\begin{array}{c}\text { Without LTS } \\
(n=114)\end{array}$ & $\begin{array}{c}\text { With LTS } \\
(n=10)\end{array}$ & OR $(95 \% \mathrm{Cl})$ & $\begin{array}{c}\text { Without LTS } \\
(\mathrm{n}=101)\end{array}$ & $\begin{array}{c}\text { With LTS } \\
(n=53)\end{array}$ & OR $(95 \% \mathrm{Cl})$ \\
\hline G / G & 85 & 6 & 1,00 & 71 & 46 & $\begin{array}{c}9.19 \\
(3.69-22.90)\end{array}$ \\
\hline G / A & 29 & 4 & $\begin{array}{c}1.98 \\
(0.62-7.52)\end{array}$ & 30 & 7 & $\begin{array}{c}3.31 \\
(1.03-10.66) \\
\end{array}$ \\
\hline $\mathrm{A} / \mathrm{A}$ & 3 & 0 & 0.00 & 0 & 0 & - \\
\hline \multicolumn{7}{|c|}{$p=0.044$} \\
\hline
\end{tabular}

We have previously demonstrated that the presence of NTG in patients with HF causes a less favorable course of heart pathology compared to patients without NTG [6]. Thus, among patients with HF, running against the background of NTG, there is a higher risk of rehospitalization (OR = $3.037(1.85-4.99), p=0.0001)$ and a CEP $(O R=2.53$ (1.60 - 3.995), $p=0.001)$ [6].
We have analyzed the association of the risk of achieving CEP, within 2 years, with the genotype of the $\beta$-ARs system in NTG in patients with HF. It is established that patients with HF running against the background of NTG having allele G of the GIn27Glu (c, 79C> $\mathrm{G})$ polymorphism of the $\beta_{2}-A R$ gene have an increased risk of achieving CEP within 2 years (OR $=3.05$ (1.10$8.43)$ in homozygous condition and OR $=3.38(1.47$ - 
7.82) in heterozygotes, at $p=0.008$ ) (table 4). The risk is also increased in heterozygous ( $\mathrm{G} / \mathrm{C}$ ) patients with the Gly389Arg (c, 1165G> C) polymorphism of the $\beta 1-A R$ gene in the presence of NTG (OR = $2.09(1.00-4.37), p=$ 0.046).

Correlation of CEP risk and $\beta$-ARs gene polymorphisms in patients with HF

\begin{tabular}{|c|c|c|c|c|c|c|}
\hline \multicolumn{7}{|c|}{ Gly389Arg $(c, 1165 G>C)$ polymorphism of $\beta_{1}-A R$ gene $(n=280)$} \\
\hline \multirow[b]{2}{*}{ Polymorphism } & \multicolumn{3}{|c|}{ Without NTG $(n=127)$} & \multicolumn{3}{|c|}{ Witht NTG $(n=153)$} \\
\hline & $\begin{array}{l}\text { Without CEP } \\
\quad(n=98)\end{array}$ & $\begin{array}{l}\text { With CEP } \\
\quad(n=29)\end{array}$ & OR $(95 \% \mathrm{Cl})$ & $\begin{array}{l}\text { Without CEP } \\
\quad(n=93)\end{array}$ & $\begin{array}{l}\text { With CEP } \\
\quad(n=60)\end{array}$ & $\begin{array}{c}\text { OR } \\
(95 \% \mathrm{Cl})\end{array}$ \\
\hline 1 & 2 & 3 & 4 & 5 & 6 & 7 \\
\hline G / G & 53 & 20 & 1,00 & 52 & 30 & $\begin{array}{c}1.60 \\
(0.80-3.19) \\
\end{array}$ \\
\hline G / C & 31 & 9 & $0.76(0.30-1.88)$ & 35 & 26 & $\begin{array}{c}2.09 \\
(1.00-4.37)\end{array}$ \\
\hline $\mathrm{C} / \mathrm{C}$ & 14 & 0 & 0.00 & 6 & 4 & $\begin{array}{c}1.62 \\
(0.40-6.45) \\
\end{array}$ \\
\hline \multicolumn{7}{|c|}{$p=0.046$} \\
\hline \multicolumn{7}{|c|}{ GIn27Glu $(c, 79 C>G)$ polymorphism of $\beta_{2}$-AR gene $(n=284)$} \\
\hline \multirow[b]{2}{*}{ Polymorphism } & \multicolumn{3}{|c|}{ Without NTG $(n=127)$} & \multicolumn{3}{|c|}{ Witht NTG $(n=157)$} \\
\hline & $\begin{array}{l}\text { Without CCP } \\
(n=97)\end{array}$ & $\begin{array}{l}\text { With CCP } \\
(n=30)\end{array}$ & OR $(95 \% \mathrm{Cl})$ & $\begin{array}{c}\text { Without CCP } \\
(n=94)\end{array}$ & $\begin{array}{l}\text { With CCP } \\
(n=63)\end{array}$ & $\begin{array}{c}\text { OR } \\
(95 \% \mathrm{Cl}) \\
\end{array}$ \\
\hline $\mathrm{C} / \mathrm{C}$ & 36 & 13 & 1.00 & 52 & 18 & $\begin{array}{c}1.00 \\
(0.43-2.32) \\
\end{array}$ \\
\hline C / G & 44 & 16 & $\begin{array}{c}1.03 \\
(0.43-2.45) \\
\end{array}$ & 29 & 32 & $\begin{array}{c}3.38 \\
(1.47-7.82) \\
\end{array}$ \\
\hline G / G & 17 & 1 & $\begin{array}{c}0.17 \\
(0.02-1.41)\end{array}$ & 13 & 13 & $\begin{array}{c}3.05 \\
(1.10-8.43)\end{array}$ \\
\hline \multicolumn{7}{|c|}{$p=0.008$} \\
\hline
\end{tabular}

No other statistically significant associations were found for other polymorphisms under study.

\section{Discussion}

HF is one of the most common causes of hospitalization and death of patients. It is known that the course of $\mathrm{HF}$, its progression, is associated with comorbidities and the dynamics of a number of biomarkers, hormones and genetic factors [7]. NTG is a diffuse or nodal enlargement of the thyroid gland, which is not due to an inflammatory or neoplastic process and is not associated with impaired gland function. According to the World Health Organization, the United Nations Children's Fund and the International Council on lodine Deficiency, in the absence of iodine deficiency (ID), the prevalence of NTG is less than $5 \%$; in mild ID the NTG incidence ranges from 5 to $20 \%$; in moderate ID the NTG develops in $20-30 \%$; severe ID raises the NTG incidence by $>30 \%$ [8]. Regular examinations using sensitive imaging techniques demonstrate a much higher incidence. In three prospective studies, the detection rate of NTG by ultrasonography made $16-67 \%$ [8]. Kharkiv and Kharkiv region, where our study was carried out, belong to regions of Ukraine with mild ID.

Unlike sporadic NTG, caused in most cases by spontaneous recessive genome alteration, family NTG represents an autosomal dominant type of inheritance [8]. The interaction of genes, or genes and various other factors (i.e. the synergistic effects of multiple variants or polymorphisms and non-genomic factors) raises the complexity of understanding the NTG pathogenesis and possibly explains its genetic heterogeneity. Defects in genes that regulate physiological processes in the thyroid gland can lead to the development of NTG in terms of borderline or overt ID.

Hypercatecholemia inherent in HF displays its effects through the $\beta$-ARs system. $\beta$-AR are paired transmembrane proteins located on cells of the whole body, includ- ing cardiomyocytes, vascular smooth myocytes and extra-vascular parenchymal organs' cells, including the thyroid gland (TG), liver [9]. Catecholamines, through $\beta-A R$, regulate the thyroid function [9] and also the activity of deiodinases, both in the gland itself and in the liver and adipose tissue [9].

There are three subclasses of AP $\left(\beta_{1}, \beta_{2}, \beta_{3}\right)$ [3]. $\beta_{1}$ and $\beta_{2}$-AR effect catecholamines to stimulate intracellular processes through a cytosolic G-protein, a heterotrimer consisting of three subunits: $\alpha, \beta$ and $\gamma$ [10]. $\beta_{1}$-AR only activates G-protein (Gs). $\beta_{2}-A R$, in addition, can also inhibit it $(\mathrm{Gi})$, reducing the production of cyclic adenosine monophosphate (cAMP), which may reduce the activity of deiodinases [10]. There is evidence that the activity of deiodinases may also depend on $\beta$-AP polymorphisms [10].

In our study, it was found that the presence of the Gallele of the Ser49Gly polymorphism of the $\beta_{1}$-AR gene is associated with an increase in the rate of NTG development (recessive heredity model, $\chi^{2}=3.719, p=0.039$ ). The risk of LTS in patients with HF running against the background of NTG grows in homozygotes (G / G) by the Ser49Gly (c, 145A> G) polymorphism of the $\beta_{1}-A R$ gene $(\mathrm{OR}=9.19$ (3.69-22.90), $p=0.044)$. The $\beta_{1}-\mathrm{AR}$ gene is localized on chromosome 10q24-26. There are two clinically significant gene polymorphisms associated with single-nucleotide substitutions: in position 49 (extracellular $\mathrm{N}$-terminal site) associated with the substitution of the amino acid serine (Ser) with glycine (Gly) and in position 389 (intracellular carboxyterminal site) where arginine (Arg) is substituted with glycine [3].

In vitro studies have shown that homozygotes with Ser (AA genotype) have lower functional adenylate cyclase activity compared to the $G$ allele carriers, but they are more sensitive to adrenaline stimulation [11]. In another study, no differences in basal adenylate cyclase activity were detected, but high sensitivity to prolonged 
agonist exposure was confirmed. It is possible to assume that allele $G$, which makes $\beta_{1}$-AR less sensitive to adrenal stimulation, leads to a decrease in the activity of peripheral deiodinases (the incidence of LTS grows) and the uptake of iodine in the thyroid gland (development of NTG).

We found a tendency to increase the rate of NTG development (by 5.9\%) in the presence of the allele-C polymorphism of the Ser275 gene $\mathrm{GN} \beta_{3}$ (recessive heredity model, $\chi^{2}=3.452, p=0.068$ ). G-proteins are expressed in all human cells. G-protein affects the classical cAMP / protein kinase pathway [10]. The active form of G-protein (Gs) in contact with the allosteric center of adenylate cyclase activates the formation of cAMP. In its turn, cAMP serves as a regulator of many enzymes activity. As a result of these and a number of other related processes, the processes of iodide absorption in the thyroid gland, its transport and incorporation into thyroglobulin structure are also activated. The most common is C825T polymorphism of the $\beta_{3}$ subunit (GNB3) gene [10].

Irrespective of the fact that $\mathrm{T}$ polymorphism is functionally inactive, it leads to truncated (alternative) splicing of exon 9 (GNB3) and ultimately to the truncated $\beta_{3}$ subunit of the $G$ protein. This altered subunit raises $\alpha$ adrenergic activation and is associated with increased activity of signaling pathways [10]. Thus, it is possible to assume that due to the functionally less active C-allele changes occur that reduce the sensitivity of thyroid gland to hypercatecholemia in the conditions of initial ID, which ultimately lead to the development of NTG [10].

In patients with HF, running against the background of NTG, in the presence of the allele-G polymorphism Gin27Glu (c, 79C> G) of the $\beta_{2}$-AR gene, the risk of CCP increases for two years $(O R=3.05(1.10-8.43)$ in the homozygous state and $\mathrm{OR}=3.38(1.47-7.82)$ in heterozygotes, at $p=0.008$ ). According to the literature, the association of GIn27Glu $\beta_{2}$-AR polymorphism with the clinical HF course is rather ambiguous. Exercise load tolerance was studied in 2002 in patients with compensated HF and it was found that patients with Arg16 / Glu27 had greater endurance compared to the Gli16 / GIn27 polymorphism group [12]. The study found that a decrease in exercise tolerance always precedes the HF decompensation [12]. Researchers studied the polymorphism of $\beta 2-$ $A R$ and $32-A R 5$ 'LC Arg19Cys in patients with idiopathic dilated cardiomyopathy [13]. The analysis revealed that Arg16 and GIn27 $\beta 2-A R$ polymorphism may be associated with a low risk of HF development.

At the same time, other scientists investigated 256 cases of HF in 2004, noting the $\beta 1$-AR Arg389Gly, $\beta 2-A R$ Arg16Gly, and GIn27Glu polymorphisms, but did not find a significant correlation with HF. In two studies, the effect of $\beta 2-A R$ gene polymorphisms on the risk of HF development and progression was investigated. The Italian study included 236 patients with HF and 230 healthy volunteers. No associations were found between Arg16Gly, GIn27Glu polymorphisms, and HF course. Another group of researchers reported the results of a randomized trial involving a large number of patients with ischemic and idiopathic cardiomyopathy. No effect of the 16 and 27 polymorphism of the $\beta 2-A R$ gene was detected on the risk of HF development and features of the HF course [14].

In our previous work, taking into account the presence of LTS, it was found that the risk of rehospitalization increases with C / G polymorphism
GIn27Glu of $\beta_{2}$-AR gene (OR $=1.25$ [0.85-1.82], $p=$ 0.025 , excessively dominant model of heredity) [16].

The risk of CEP also grows in heterozygous ( $\mathrm{G} / \mathrm{C}$ ) patients with HF by the Gly389Arg (c, 1165G> C) polymorphism of the $\beta 1-A R$ gene in the presence of NTG $(\mathrm{OR}=2.09$ (1.00-4.37), $p=0.046)$. The Arg389Gly polymorphism of the $\beta 1-A R$ gene encodes the substitution of Gly with Arg389 [16]. In the Gly389 gene polymorphism, $\beta_{1}$-AR have low sensitivity to exogenous stimulation (natural blockade) [16]. There is evidence of a prolonged hospital stay in the patients-carriers of the Gly389 allele of the Arg389Gly polymorphism who underwent cardiac surgery [16].

\section{Conclusion}

The findings suggest that congenital genetic differences in $\beta$-adrenoreception pathways may be associated with the development of nontoxic goiter and affect the two-year course of heart failure.

The presence of the G-allele of the Ser49Gly polymorphism of the $\beta_{1}$-adrenoceptors gene is associated with an increase in the rate of nontoxic goiter development.

The risk of developing "low triiodothyronine" syndrome in patients with heart failure, which runs against the background of nontoxic goiter, increases in homozygotes ( $G / G$ ) by the Ser49Gly (c, 145A> G) polymorphism of the $\beta_{1}$-AR gene.

Patients with heart failure running against the background of non-toxic goiter, carriers of the $G$ allele in GIn27Glu (c, 79C> G) polymorphism of the $\beta_{2}$-AR gene, have the risk of reaching a combined endpoint within two years. The risk is also increased in heterozygous ( $G / C)$ patients with the Gly389Arg (c, 1165G > C) polymorphism of the $\beta 1-A R$ gene in the presence of non-toxic goiter.

\section{References}

1. 1. Kolomoyets MYu, Vashenyak OO Komorbidnist i polimorbidnist u terapevtychniy praktytsi. Ukrayinskyi medychnyi zhurnal. 2012; 5 (91):9-10. [in Ukrainian]

2. Bonnema SJ, Hegedus L A 30 year perspective on radioiodine therapy of benign nontoxic multinodular goiter. Cur Op Endocr Metab Diab Obes. 2009; 16:379-384.

3. Brodde OE Beta(1) and beta(2) adrenoreceptor polymorphisms: Functional importance, impact on cardiovascular diseases and drug responses. Phrmacol Ther. 2008; 117 : 1-29.

4. Ponikowski P, Voors AA, Anker SD ESC guidelines for the diagnosis and treatment of acute and chronic heart failure: the task force for the diagnosis and treatment of acute and chronic heart failure of the European Society of Cardiology (ESC). Developed with the special contribution of the heart failure association (HFA) of the ESC. Eur J Heart. Fail. 2016.

5. Pyvovar S, Rudyk I, Lozyk T Sindrom «nizkogo triyodtironina» i techeniye serdechnoy nedostatochnosti. Georgian Medical News. 2019; 4 (289): 79-85. [in Russian]

6. Pyvovar S, Rudyk I, Lozyk T Prohnozuvannya perebihu sertsevoyi nedostatnosti u khvorykh $z$ netoksychnym zobom z urakhuvannyam funktsiyi shchytopodibnoyi zalozy. ScienceRise. Medical Science. 2019; 4.

7. Ma ST, Zhao W, Liu D Association between $\beta_{1}$ adrenergic receptor gene Arg389Gly polymorphism and risk of heart failure: a meta-analysis. Genet Mol Res. 2015; 14: 5922-9.

8. Krohn KD, Führer Y, Bayer M Molecular Pathogenesis of Euthyroid and Toxic Multinodular Goiter. Endocr Rev. June 2005; 26(4): 504-24.

9. Kim C, Reed L Thyroid Hormone and Adrenergic Signaling. Arq Bras Endocrinol Metab. 2004; 48(1): 171-175.

10. Sheppard R, Hsich E, Damp J. Investigators GNB3 C825T Polymorphism and Myocardial Recovery in Peripartum Cardiomyopathy Results of the Multicenter Investigations 
of Pregnancy-Associated Cardiomyopathy Study. Circ Heart Fail. 2016; 9: e002683

11. Rathz DA, Brown KM, Kramer LA Amino acid 49 polymor phisms of the human beta1adrenergic receptor affect agonistpro moted trafficking. J Cardiovasc Pharmacol. 2002; 39: 155-160.

12. Panebra A, Wang WC, Malone MM Common ADRB2 haplotypes derived from 26 polymorphic sites direct beta2adrenergic receptor expression and regulation phenotypes. PLoS One. 2010; 29: e11819.

13. Covolo L, Gelatti U, Metra M Role of beta1- and beta2adrenoceptor polymorphisms in heart failure: a casecontrol study. Eur Heart J. 2004; 25: 1534-1541.
14. Levin M, Marullo S, Muntaner O The myocardium protective Gly49 variant of the beta1 adrenergic receptor exhibits of consti tutive activity and increased desensitization and down regulation. J Biol Chemistry. 2002; 277: 3042930435.

15. Pyvovar S, Rudyk I, Lozyk T Vzaémozyazok polimorfizmu heniv systemy $\beta$-adrenoretseptsiyi $z$ syndromom «nyzkoho» tryyodtyroninu u khvorykh $\mathrm{z}$ sertsevoyu nedostatnistyu. Polski merkuriusz lekarski. 2019. 4

16. Wagoner L, Craft L, Zengel P Polymorphisms of the betaladrenergic receptor predict exercise capacity in heart failure. Am Heart J. 2002; 144: 840-846.

Матеріал надійшов до редакції 02.10.2019. 